\title{
First Confirmed Report on Powdery Mildew of Phlox paniculata Caused by Golovinomyces magnicellulatus in Korea
}

\author{
Mi-Jeong Park ${ }^{1}$, Ji-Hyun Park ${ }^{1}$, Soon-Gu Lee ${ }^{2}$ and Hyeon-Dong Shin ${ }^{1 *}$ \\ ${ }^{1}$ Division of Environmental Science and Ecological Engineering, Korea University, Seoul 136-701, Korea \\ ${ }^{2}$ Department of Plant Medicine, School of Bioresource Science, Andong National University, Andong 760-749, Korea \\ (Received on March 3, 2010; Accepted on April 28, 2010)
}

Garden phlox (Phlox paniculata L.), belonging to the Polemoniaceae, is a perennial plant with large heads of blossoms, providing great garden color and fragrance in summer. The plant is native to North America and known to be introduced in Korea at the beginning of the $20^{\text {th }}$ century. Various horticultural varieties are widely planted for ornamental purposes in Korea. Powdery mildew infections on leaves (Fig. 1A) and inflorescence (Fig. 1B) are rather common and troublesome in gardening of this plant in Korea. However, the identity of the causal fungus has not been determined due to lack of teleomorphic state.

In August 2009, powdery mildew lesions with abundant chasmothecia were found on P. paniculata for the first time in Andong, Korea (Fig. 1C). Further surveys in several localities in Korea including Yeongwol, Jeongseon and Yanggu showed that this powdery mildew fungus is commonly found in these places with mature chasmothecia. The phenomenon was rather surprising, because only conidial state of powdery mildew has been found on this plant (Kwon and Park, 2003; Shin, unpublished data). The voucher specimens are kept at Korea University (KUS-F24480, F24739).

The conidiophores were 70-240 $\mu \mathrm{m}$ long and producing 2-6 immature conidia in chains with sinuate edge-line. Conidia were ellipsoid or doliiform, 25-35 $\times 12.5-17.5 \mu \mathrm{m}$, and without distinct fibrosin bodies. Chasmothecia were dark brown, spherical, 100-150 $\mu \mathrm{m}$ in diam. and contained several asci(Fig. 1D). Appendages were
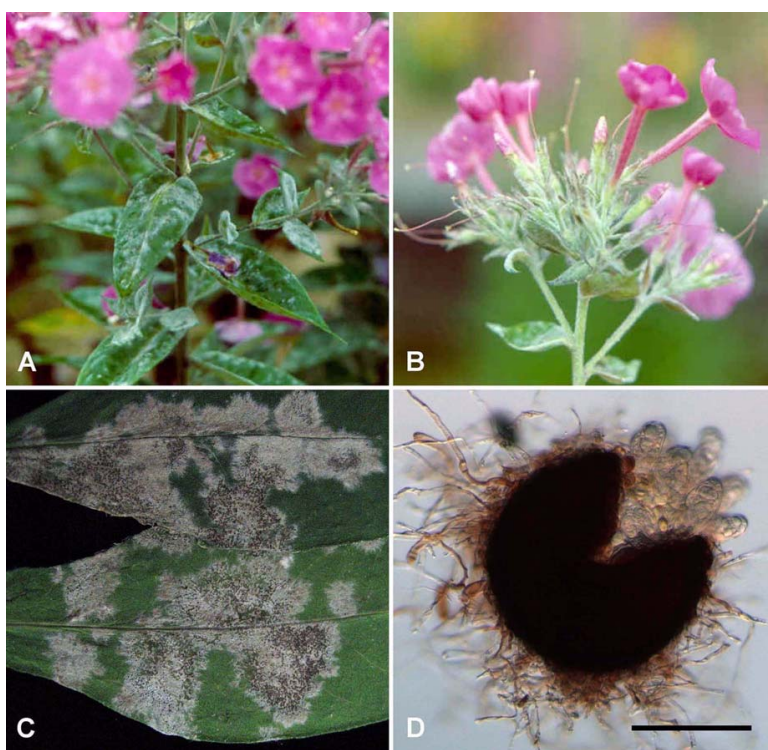

Fig. 1. Symptoms of powdery mildew on leaves (A) and inflorescence (B) of Phlox paniculata infected with Golovinomyces magnicellulatus. (C) Close-up view of powdery mildew lesions on leaves of $P$. paniculata. Note the numerous blackish structures, overwintering chasmothecia of $G$. magnicellulatus, on the powdery mildew colonies. (D) A chasmothecium containing several 2-spored asci $($ Bar $=100 \mu \mathrm{m})$. mycelioid, $12-28$ per chasmothecium, $0.5-2.5$ times as long as the chasmothecial diam., 1-5-septate. Asci were shortly stalked, 55$75 \times 25-37 \mu \mathrm{m}$ and 2-spored. Ascospores were ellipsoid-ovoid and $22-32 \times 15-22 \mu \mathrm{m}$. These morphological characteristics are in good agreement with those of previous records of Golovinomyces magnicellulatus (Braun, 1987; Tanda, 1997).

The complete ITS rDNA of the two isolates was amplified with primers ITS5 and P3 and directly sequenced. The sequences obtained were identical to each other and deposited in GenBank (accession nos. GU945756, GU945757). Phylogenetic analysis was carried out using MEGA4 with neighbor-joining method (using Tajima-Nei distances). Comparison with the sequences available in the GenBank database revealed that the ITS sequences share $100 \%$ similarity (512/512 bp) with a sequence of $G$. magnicellulatus on $P$. paniculata (AB077621) from Japan and $99 \%(510 / 512$ bp) with that of G. magnicellulatus on the same host (AF011303) from the USA. Therefore, the sequence analysis confirmed the identity of the pathogen as $G$. magnicellulatus.

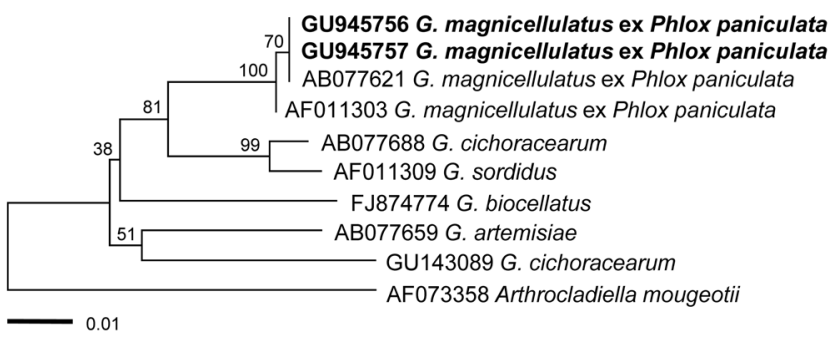

Fig. 2. Phylogenetic relationship between Golovinomyces magnicellulatus on Phlox paniculata and other Golovinomyces species, inferred by neighbor-joining method using DNA sequences of the ITS rDNA region. Numbers above the branches represent the bootstrap values. Bar $=$ Number of nucleotide substitutions per site.

Powdery mildew on P. paniculata caused by G. magnicellulatus was recorded from North America and extended to Europe (Braun, 1987) and recently found in Japan (Tanda, 1997). Powdery mildew on this plant in Korea was first recorded as Oidium sp. by Kwon and Park (2003). Their description and figures suggest that the fungus is an anamorphic state of $G$. magnicellulatus. Therefore the present work is the first well-founded report of G. magnicellulatus on Phlox in Korea although this pathogen is likely to have been present for years before now.

\section{References}

Braun, U. 1987. A Monograph of the Erysiphales (Powdery Mildews). Beihefte zur Nova Hedwigia 89:1-700.

Kwon, J. H. and Park, C. S. 2003. Powdery mildew on Phlox caused by Oidium sp. in Korea. Korean J. Mycol. 31:50-52.

Tanda, S. 1997. Identification of some Erysiphe fungi found on three species of herbaceous plants. J. Agric. Sci., Tokyo Univ. Agr. 41:202-210.

*Corresponding author (hdshin@korea.ac.kr) 